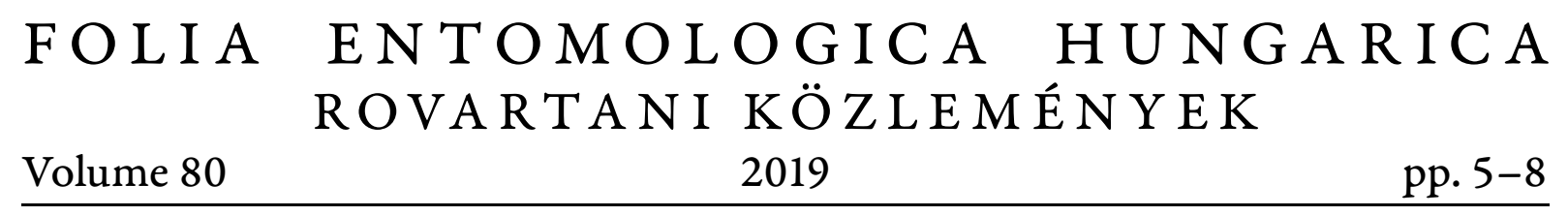

\title{
First record of Gryllomorpha dalmatina from Hungary (Orthoptera: Gryllidae)
}

\author{
Márk LÁsZLó \\ H-1215 Budapest, Ady Endre út 49, Hungary.E-mail: laszlomark.orthopt@gmail.com
}

\begin{abstract}
An adult female individual of Gryllomorpha dalmatina Ocskay, 1832 was observed at the beginning of October 2019 in Gyarmat, Hungary. The cricket was found in an old tub inside a disused part of a house. It was not the first time that this species was seen in a building outside the Mediterranean part of Europe, however it is its first Hungarian record. With one figure.
\end{abstract}

Key words - introduced species, distribution, new record

\section{INTRODUCTION}

The genus Gryllomorpha Fieber, 1853 (Orthoptera: Gryllidae: Gryllomorphinae: Gryllomorphini) is widely distributed in the Mediterranean region and the Middle East (Alexiou et al. 2017). Eight species are known in Europe (HOCHKIRCH et al. 2016), six of them inhabit the continental part of the Mediterranean region of Europe, while two species are endemic to Crete and Canary Islands. No species of the genus is native in Hungary.

G. dalmatina is the largest member of the genus (Gorochov 2009). Males and females are apterous just like the other congeneric species. G. dalmatina is distributed from Catalonia and Balearic Islands on the west to Crimea and Turkey on the east (MARCHESI \& FOURNIER 2006). The northernmost known populations are in South Tyrol, Italy and in southern Switzerland (KoLlmanN 1999). However, there are no data of living populations north of the Alps, although a few individuals were observed in Belgium and Germany.

According to the dataset of Global Biodiversity Information Facility (GBIF SeCRETARIAT 2019) two specimens were found in Belgium in 1982 and 1989, less than $60 \mathrm{~km}$ from each other. These individuals were collected and preserved. In 1998 Andreas Kollmann caught a male in his cellar in Landeck, Germany, and identified it as $G$. dalmatina (KolLm ANN 1999). This is an example of the fact that this nocturnal cricket is often linked to human-made constructions such as cellars, ruins or stonewalls (MARCHESI \& FOUR NIER 2006). 
In 2015 Michael Happ found a male in Germany but in a field of Eilenburg. The species is not native in Belgium and Germany, so the presence of the mentioned individuals in these countries is certainly the consequence of human activities like long-distance transportation or importations from the south.

\section{MATERIAL AND METHODS}

The female individual of $G$. dalmatina (Fig. 1) was found in a disused part of a house in Gyarmat (Györ-Moson-Sopron county, western Hungary, $47.47^{\circ} \mathrm{N}, 17.50^{\circ} \mathrm{E}$ ), on 2 nd October, 2019. The cricket was in an old tub and could not get out because of the tub's smooth surface. The windows of the room were opened for a while, that was the most likely way the cricket was able to enter the building and get trapped in the tub. A few days later the individual died, but its remains (containing the metathorax, the abdomen and the ovipositor) were preserved in $70 \%$ ethanol.

The length of the ovipositor was measured from its base to the apex, and it turned out to be $14.5 \mathrm{~mm}$ long.

In order to find other individuals or an occurrent population, pitfall traps $1 / 3$ full of water with some dish soap - to lower surface tension- were placed in different locations in the garden. Some of them were partially covered with laths in the way that these crickets would be able to get trapped.

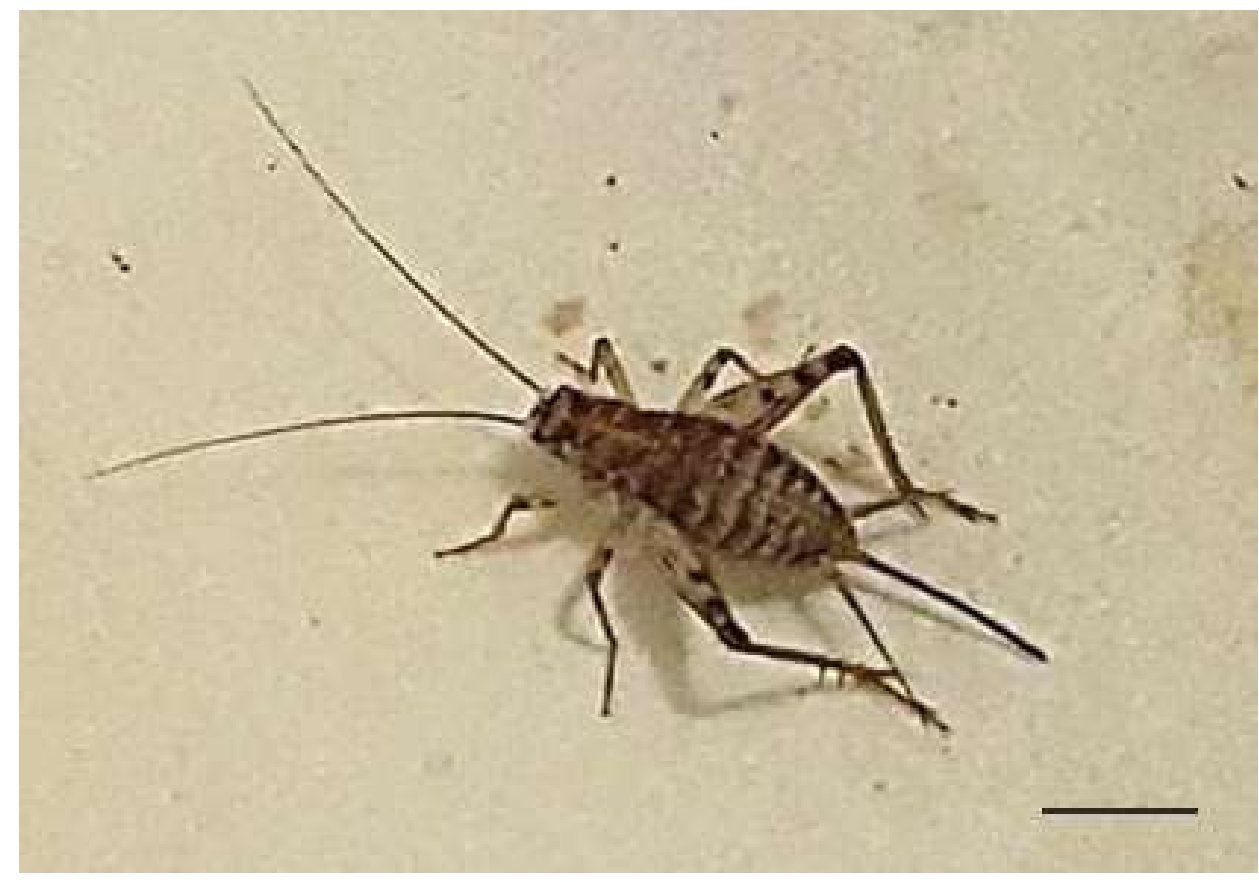

Fig. 1. Photo of Gryllomorpha dalmatina Ocskay, 1832 taken right after the observation of the individual. Scale $=10 \mathrm{~mm}$ (photo by Dániel Fintor) 


\section{RESULTS AND DISCUSSION}

The identification of the specimen was mostly based on the length of ovipositor with which the females of the European Gryllomorpha species can be distinguished (HARZ 1969). The characteristics of the specimen's colouration like the dark and pale patterns of the head (GoRochov 2009) and its habit were also proper to $G$. dalmatina.

The pitfall traps were checked regularly but only other arthropods were caught. The search in the cellar and in the surroundings of the house also did not bring any results. Because of the cold temperatures towards the end of October the traps were picked up in November without any other crickets.

Although the origin of the observed individual is unknown, its presence was most probably connected to human activity, for example importations from the Mediterranean countries. Despite only one female was detected, there is the chance that a small population could survive in this built-up area where the winters are less severe due to the heating effect of the town, just like in the case of a newly discovered population of a Mediterranean bush-cricket Eupholidoptera garganica La Greca, 1959 in Albertfalva, Budapest, Hungary (Puskás 2018). To investigate this assumption further research will be performed.

Acknowledgements - I would like to thank Dániel Fintor (Gyarmat) for the first known picture of $G$. dalmatina taken in Hungary and the helpful attitude in order to find another individual of this species in Gyarmat.

\section{REFERENCES}

Alexiou S., Zacharias S. \& Bakolitsas K. 2017: The Gryllomorphinae (Gryllidae, Orthoptera) of Greece. A synopsis and new distribution data. - Parnassiana Archives 5: 29-34.

GBIF SeCRETARIAT 2019: Gryllomorpha dalmatina (Ocskay, 1832). - In: GBIF Backbone Taxonomy. Checklist dataset. https://doi.org/10.15468/39omei [Accessed via GBIF.org on 16 November 2019.]

Gorochov A. V. 2009: A study of the genus Gryllomorpha Fieber, 1853 (Orthoptera: Gryllidae: Gryllomorphinae). - Zoosystematica Rossica 18(1): 25-47.

Harz K. 1969: Die Orthopteren Europas. Band 1. The Orthoptera of Europe. Volume I. - Dr. W. Junk N. V., The Hague, 749 pp. 
Hochirirch A., Nieto A., García Criado M., Cálix M., Braud Y., Buzzetti F. M., Chobanov D., Odé B., Presa Asensio J.J., Willemse L., Zuna-Kratky T., Barranco Vega P., Bushell M., Clemente M. E., Correas J. R., Dusoulier F., Ferreira S., Fontana P., García M. D., Heller K.-G., Iorgu I.Ș., Ivković S., Kati V., Kleukers R., Krištín A., Lemonnierdarcemont M., Lemos P., Massa B., Monnerat C., Papapavlou K. P., Prunier F., Pushikar T., Roesti C., Rutschmann F., Şirin D., Skejo J., Szövényi G., Tzirkalli E., Vedenina V., Barat Domenech J., Barros f., Cordero Tapia P. J., Defaut B., Fartmann T., Gomboc S., GutiérrezRodríguez J., Holuša J., Illich I., Ka RJa lainen S., KoČárek P., Korsunovskaya O., liana A., López H., Morin D., Olmo-Vidal J. M., Puskás G., Savitsky V., StAlling T. \& Tumbrinck J. 2016: European Red List of grasshoppers, crickets and bush-crickets. - Publications Office of the European Union, Luxembourg, 86 pp. https://doi.org/10.2779/60944

Kollmann A. 1999: Fund der Stummen Grille (Gryllomorpha dalmatina) in Landeck (Südbaden). - Articulata 14(1): 63.

MARChesi P. \& Fournier J. 2006: Le grillon des bastides (Gryllomorpha dalmatina Ocskay 1832), une nouvelle espèce d'orthoptère pour le Valais. - Bulletin de la Murithienne Société valaisanne des sciences naturelles 124: 59-61.

PUSK Ás G. 2018: Eupholidoptera garganica (Orthoptera: Tettigoniidae) in Budapest, Hungary. Foliaentomologicahungarica 79:37-43.https://doi.org/10.17112/FoliaEntHung.2018.79.37 